\title{
THE CURRENT CHALLENGES AND FUTURE ALTERNATIVES OF SUPPLYING REMOTE AREAS WITH BASIC GOODS: THE CASE STUDY OF IDRIJSKO-CERKLJANSKO REGION, SLOVENIA
}

\author{
Barbara Kostanjšek $^{1}$, Naja Marot ${ }^{2}$
}

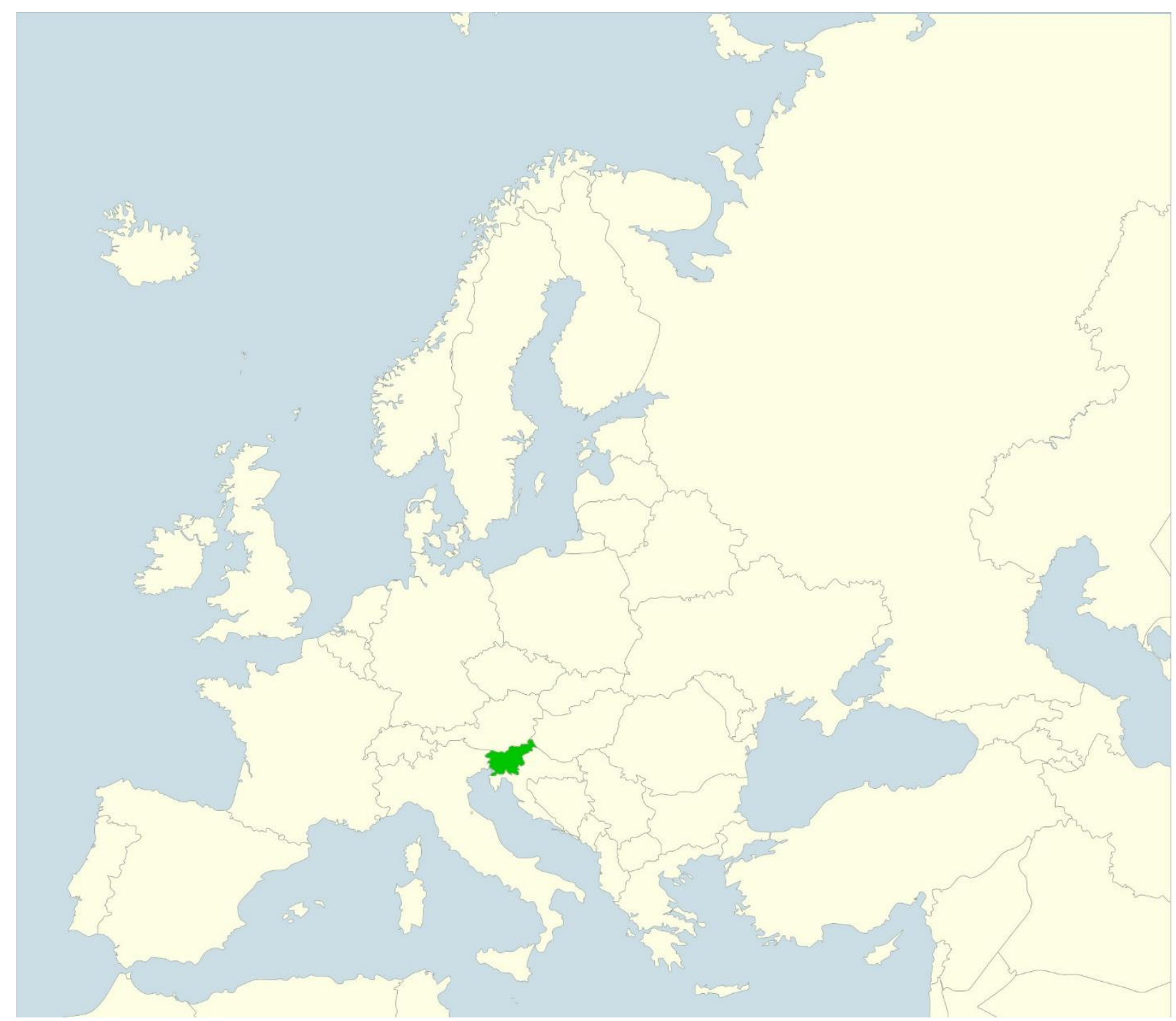

\footnotetext{
${ }^{1}$ Barbara Kostanjšek, M.Sc. of Landscape Architecture - Department of Landscape Architecture, Biotechnical Faculty, University of Ljubljana, Slovenia. ORCID: 0000-0003-1857-1576, e-mail: barbara.kostanjsek@bf.uni-lj.si

${ }^{2}$ Assist. Prof. Dr. Naja Marot - Department of Landscape Architecture, Biotechnical Faculty, University of Ljubljana, Slovenia. ORCID: 0000-0002-5534-7592, e-mail: naja.marot@bf.uni-lj.si
} 
Abstract: The accessibility of services of general interest (shops, post offices, banks etc.) in rural hinterlands is decreasing and villages that once supplied areas with services are losing their functions in the central settlements' network. According to the current analytical framework the key challenges of supply are people's dependence on car transportation, lack of village shops and other basic services, and e-services replacing location-based services. This paper examines the current dynamics of the supply of basic goods in the Idrijsko-Cerkljansko region of Slovenia. Using mixed methods approach, the paper covers a historical overview of service provision by a field survey and historical analysis, as well as an analysis of demand and supply, done via an online questionnaire. The aim of the paper is to combine the findings into a proposal for an optimized alternative supply network integrating good practices such as linking providers, promoting local products and reopening of village shops.

Key words: services of general interest, rural areas, accessibility, basic goods, central places, centrality, retail geography, integration

Izvleček: Dostopnost storitev splošnega pomena (trgovine, pošte, banke itd.) v podeželskem zaledju upada, posledično pa podeželske vasi, ki so imele nekoč vlogo centralnih naselij $v$ smislu oskrbe podeželja, izgubljajo ključne storitve. Glede na analitični okvir so glavni izzivi ponudbe osnovnih dobrin odvisnost prebivalstva od avtomobilskega prevoza, pomanjkanje vaških trgovin, drugih osnovnih dobrin ter e-storitve, ki nadomeščajo fizične storitve. Prispevek obravnava trenutno dinamiko oskrbe z osnovnimi dobrinami na območju Idrijsko-Cerkljanskega. Raziskava z uporabo mešanih metod zajema zgodovinski pregled zagotavljanja storitev $s$ terenskim pregledom in historično analizo, analizo ponudbe in povpraševanja, opravljeno $s$ pomočjo spletne ankete, ter pregled dobrih praks. Namen raziskave je združiti ugotovitve $v$ predlog optimizirane mreže alternativne oskrbe, upoštevajoč tudi dobre prakse, kot so povezovanje ponudnikov, promocija lokalnih prehrambenih produktov in ponovno odprtje vaških trgovin.

Ključne besede: storitve splošnega pomena, podeželje, dostopnost, osnovne dobrine, centralna naselja, centralnost, ekonomska geografija, integracija

Zusammenfassung ${ }^{3}$ : Die Zugänglichkeit zu Dienstleistungen der allgemeinem Daseinsfürsorge (Geschäfte, Postämter, Banken usw.) im ländlichen Hinterland nimmt ab. Dörfer, die einst diese Gebiete mit Dienstleistungen versorgten, verlieren ihre Funktionen im System der zentralen Orte. Nach dem derzeitigen analytischen Rahmen sind die wichtigsten Herausforderungen bei der Versorgung solcher Räume die Abhängigkeit der Bevölkerung vom Autoverkehr, der Mangel an Dorfläden und anderen, grundlegenden Infrastrukturen, sowie elektronische Dienste, die standortbezogene Dienste ersetzen. Der vorliegende Beitrag untersucht die aktuelle Dynamik der Versorgung mit Gütern der Daseinsfürsoge in der Region Idrijsko-Cerkljansko in Slowenien. Der multi-methoden Ansatz dieser Untersuchung umfasst einen historischen Überblick zum Dienstleistungsangebot durch eine Feldstudie und eine historische Analyse, sowie eine Analyse zu Angebot und Nachfrage via OnlineBefragung. Auf Basis von good practices wird ein Vorschlag für ein optimiertes Versorgungsnetz erarbeitet, welches eine Vernetzung von Anbietern, die Förderung lokaler Produkte und die Wiedereröffnung von Dorfläden vorsieht.

Schlüsselwörter: Dienstleistungen der allgemeinen Daseinsfürsorge, ländliche Gebiete, Erreichbarkeit, Grundgüter, zentrale Orte, Zentralität, Einzelhandelsgeographie, Integration

\footnotetext{
${ }^{3}$ Translation of the abstract into German was provided by Jörn Harfst, University of Graz, Austria.
} 


\section{Highlights}

- In the last 20 years, most of the services providing basic goods in remote villages in the investigation area have closed down. Simultaneously, the trend of centralisation of services in the regional centre is highly evident. Thus, the service buildings are not in use anymore and are left to decay.

- Population in the area has adapted to changed conditions and using car as a transportation measure to reach services, mostly they need half an hour in time to reach them.

- The use of alternative forms of services provision is not very frequent. In addition, inhabitants provided suggestions for the improvement of supply including more local products, better delivery of goods purchased on-line, more sale of products via the local markets etc.

- Based on the former and current supply and demand, the possible solutions are proposed to improve the existing network of services of general interest in the area by creating village supply nodes. The model rests on combination of on-line shopping, local community centres, improved delivery of goods and spatial planning solutions.

\section{Introduction}

The remote areas of alpine regions are characterised with similar geographical features, such as harsh topographies, dispersed settlements, poor accessibility and transport connections, and above, all demographic change (Bausch et al., 2014; Syssner and Meijer, 2017; Čede et al., 2018; Marot, Gantar and Černič Mali, 2015; Marot et al., 2018a). Shrinking populations and their aging contribute not only to the loss of services of general interest (shorter SGI) but also the uneven distribution of these services with most being concentrated in the central towns of the regions (Humer and Palma, 2013; Nieto Masot and Alonso, 2015). This is the opposite to the process witnessed in cities in which retail services are relocating to city outskirts (e.g. Barata-Salgueiro and Erkip, 2014; Teller, Wood and Floh, 2016; Twardzik and Heffner, 2019; Delage et al., 2020). In rural and remote areas, there is a significant decline in the number of providers especially of basic goods (including food stores, post offices and banks, as well as pharmacies) and an increase in time and/or distance accessibility of services (Egger et al., 2011; Arcelus et al., 2015: Guiliani et al., 2017a). For illustration, the research of Delage et al. (2020) showed that in a 40-year period, a third of the municipalities in France have been affected by a decline in shop diversity due to demographic change, retail positioning, and commuting. The lack of services, especially basic goods, further contributes to the spiral of decline or negative development cycle according to Myrdal (1957).

Although access to basic goods should be secured by each of EU member states, because it is written in the Charter of Fundamental Rights of the European Union (2012) and considered a public good, practice shows a different picture. The retail sector including postal services and pharmacies is fully regulated by the market and dependent on economies of scale (SAB, 2007; Egger et al., 2011). Such services therefore only continue to be provided where there are sufficient numbers of costumers; most alpine villages and smaller towns are too sparsely populated (Arcelus et al., 2015; Benkovič Krašovec, 2006, Christoffersen and Bo Larsen, 2007, Page et al., 2018, van Meeteren and Poorthuis, 2017) to fulfil this criterion. In addition to the poorer provision that these rural settlements experience, many are also losing central settlement's functions, which diminished their political power on the regional level. The field survey and supply analysis on which this article is based (Kostanjšek, 2018) showed the evident trend of service centralisation in the regional centre of Idrija and how this led to a concurrent reduction in the number and diversity of services in the town's rural hinterland. This is contradictory to the territorial cohesion goal of the European Union because regional imbalances between the areas are increasing instead of decreasing. According to ESPON (2013), the Member States of the EU are having difficulty achieving the political goals, which aim to provide access and quality supply of services of general interest throughout the EU and were set in the Territorial Agenda 2020 (Ministers for Urban Development and Territorial Cohesion, 2007). 
In addition to the Services Directive in the Internal Market (European Parliament, 2006) regulating the operation of the common market, Territorial Agenda is one of the few documents that addresses the topic at an EU level since service provision is similar to spatial planning; primarily in the domain of Member States. Also, the draft of the new Territorial Agenda 2030 (Spatial Foresight, BMI and BBSR, 2020) under the pillar "A Just Europe" calls for future perspectives for all places and people and under the priority "balanced Europe" argues for the improvement of working, living and business conditions in all places.

The European Commission, more precisely the DG of Regional and Urban Policy, once aware of this development hurdle and policy gap, ordered a detailed study on the services of general interest (shorter SGI) in which they analysed Member States' situations with regard to the provision of SGI, and identified existing models and innovative examples to overcome the weaknesses of the market provision of SGI. One of the identified problems was that specific national policies for the provision of SGI are missing; confirmed in the alpine context by Egger et al. (2011) and Kolarič et al. (2017). Consequently, Guiliani et al. (2017) claimed that for the provision of basic goods in alpine and other remote rural areas, it was of foremost importance to establish a set of policy measures and hence develop suitable benchmarks taking into consideration the specific characteristics of remote areas, such as settlements (dispersion, structure, demography) and landscape features, since these are key factors which impact accessibility. In order to do that, detailed information as to the current state of the provision of basic goods in such areas is needed.

This article reflects on the provision of basic goods in the alpine mountain areas on one case study region within Slovenia. The research questions addressed are: What are the exact needs of people today with regard to the provision of basic goods? How do people fulfil these needs due to the decrease in the provision alternatives? What are the potential solutions to overcome the present deficiencies in the provision of basic goods in remote areas? The article is structured into five parts. In the first part, we present the region we investigated. In the second part, we give an overview of the methodology. In the third, the results of the study are presented and in the fourth and fifth part, the discussion is supported with an example of how services could be supplied in the future built on good practice analysis and experiences in the region. The article concludes with a reflection on how the findings compare with those of similar studies and with guidelines for how rural areas could become more resilient with regard to the supply of basic goods.

\section{Brief description of the area}

Idrijsko-Cerkljansko is an area of $426 \mathrm{~km}^{2}$ located in western Slovenia within the Goriška statistical region (see Figure 1). The latter comprised a population of approximately 120,000 inhabitants in 2018 and envelops 13 municipalities. The region has the largest share of elderly people in Slovenia, aged 80 or more (5.7\%, the Slovenian average is $5 \%$ ). The Municipality of Idrija measures $294 \mathrm{~km}^{2}$ and is the $8^{\text {th }}$ largest municipality in Slovenia by size. The Municipality of Cerkno covers $132 \mathrm{~km}^{2}$ and is a medium-sized municipality in terms of the area size (Statistical Office of the Republic of Slovenia, 2018).

The area is characterized by a transition of topography from alpine hills to the Dinaric-Karst area (plateaus) and therefore lies between two different geographical macro regions (Perko, 1998). The area consists of the central valley of the Idrijca River and high plateaus with scattered settlements, steep slopes, and several deep valleys. Larger settlements with the largest share of population, along industry and services such as Idrija (also a past mining centre), Cerkno, and Spodnja Idrija are located in the valleys and are exceptions to the existing settlement pattern in the area (Marušič et al., 1998). As visible in Figures 3a and 3b, the typical architecture, hilly cultural landscape, and grassland define the landscape characteristics of the area. 


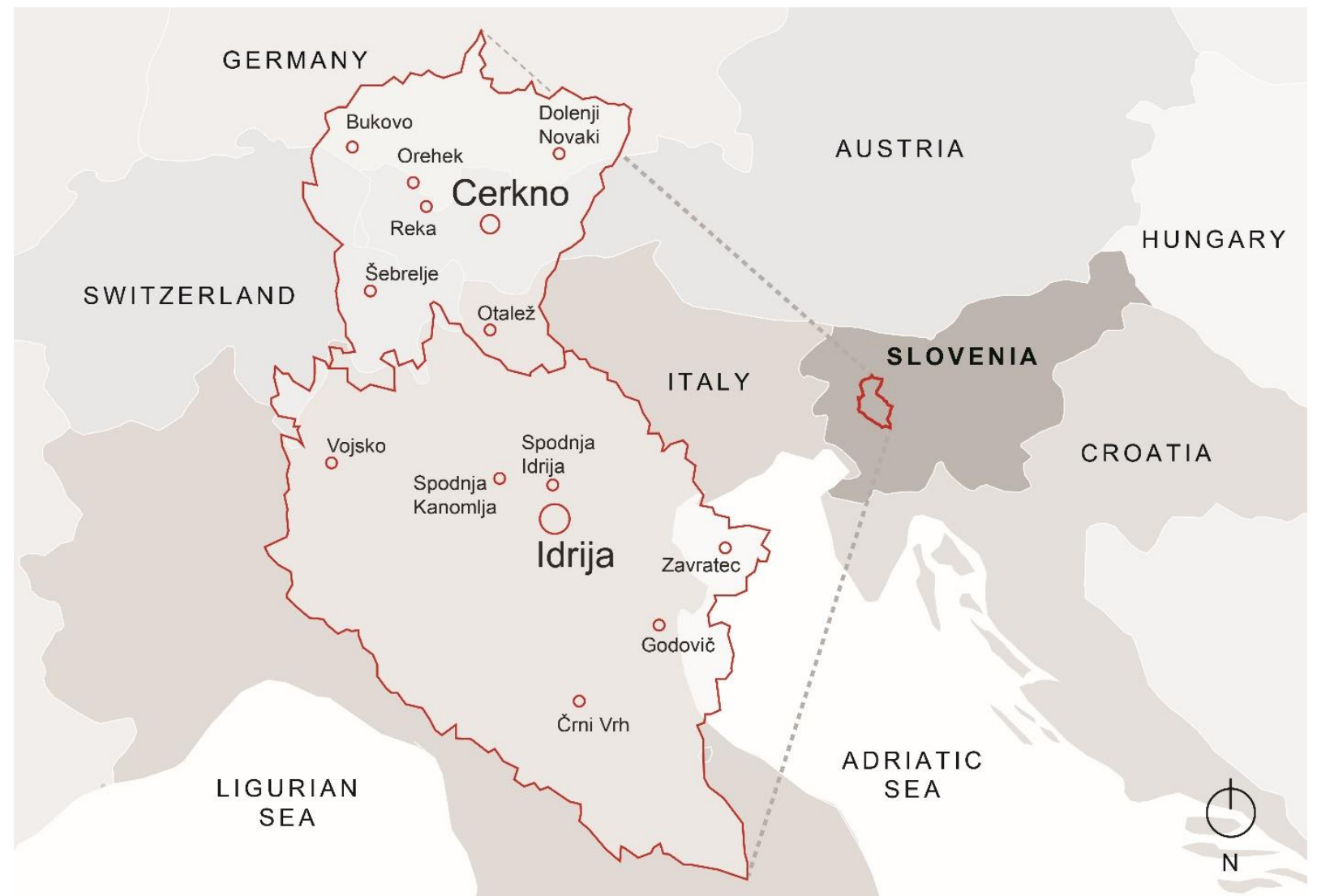

Fig 1. Map of the area of Idrijsko-Cerkljansko. Author: Barbara Kostanjšek, map source: Eurostat

This pre-alpine hilly area is characterized by low population density (39 inhabitants $/ \mathrm{km}^{2}$, Slovenia $102 \mathrm{inh} . / \mathrm{km}^{2}$ ). More than half of the population (61.8\%) live in the town of Idrija - the centre of this region, the remaining $38.2 \%$ in the countryside. In contrast, in the Municipality of Cerkno, $67.5 \%$ of the population live in rural settlements. The share of elderly residents in both municipalities who reside within urban settlements is higher than in the rural areas. Statistical data indicates a gradual decline in the number of inhabitants in the area. Similarly, the demographic forecast for the period up to 2030 shows a continuation of the declining population trend, a decrease in those aged under 14 of about $9 \%$, and an increase in the share of people over 65 of about 14\% (Giuliani et al., 2017a) Currently, in year 2020, the number of the population is at 16,725 (Statistical Office of the Republic of Slovenia, 2020). In ten years' period $2020 / 2010$, the population dropped altogether $-2.4 \%$ in the region; $-4.2 \%$ in the Municipality of Cerkno and $-1.1 \%$ in the Municipality of Idrija.

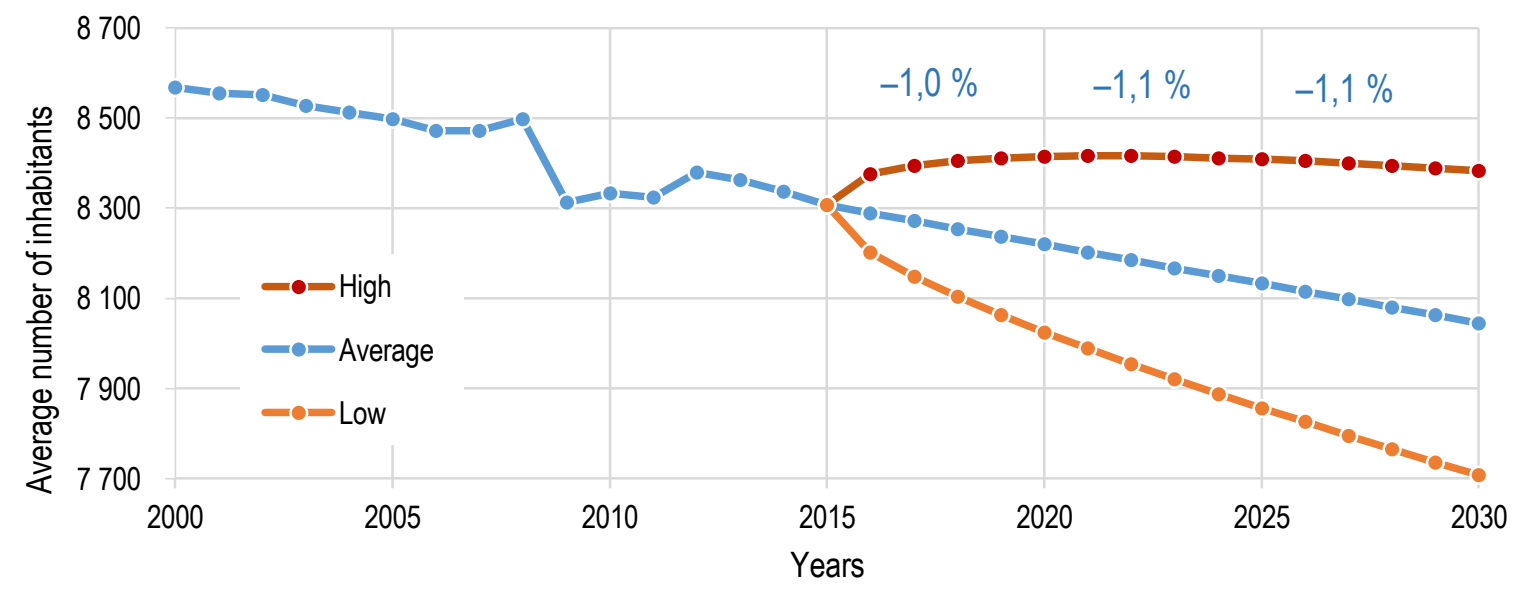

Fig 2. Demographic trend in the Idrijsko-Cerkljansko area. Source: Giuliani et al., 2017a 
In the past, mercury mining and industry were of crucial economic significance to this region. The mining activity (the last mine closed since 1990) was replaced by a growing electrical engineering industry. Today, the industries in the Idrijsko-Cerkljansko area are energy production, electrical engineering, and construction. Idrija is the seat of two successful multinationals Hidria and Kolektor; both are important employers in the region and the municipality has the highest employment rates in the country; with 513 jobs per 1,000 inhabitants, Idrija significantly exceeds the Slovenian average of 286 jobs per 1,000 inhabitants. The added value per inhabitant is 14.54 euros; twice that of the Slovenian average (Jankovič, 2017).

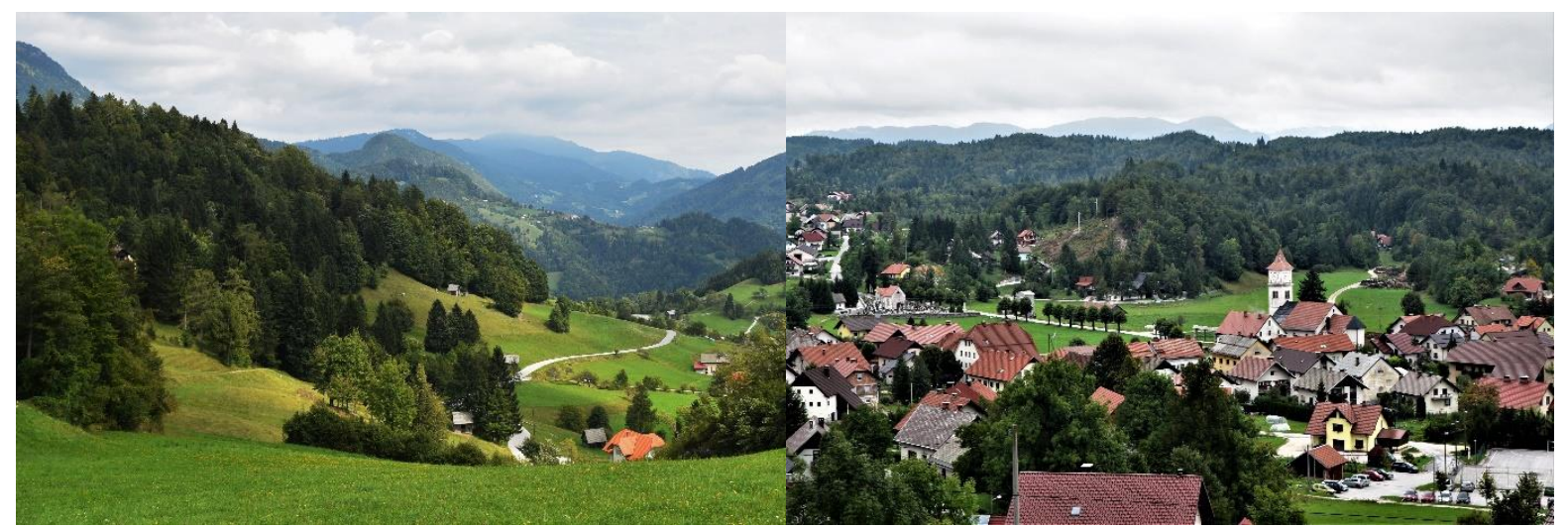

Fig $3 a$ and 3b. Characteristic landscapes of Idrijsko-Cerkljansko: dispersed settlement in hilly landscape (left), a nucleated settlement on the karst plateau adapted to the topography (right). Author: Barbara Kostanjšek

\section{Methodology}

\subsection{Basic definitions}

This paper researches challenges concerning the accessibility and availability of basic goods in rural areas. Basic goods are defined as "goods which are intended to meet basic human needs" existing in material and non-material forms and are provided by SGI, according to Kostanjšek (2018), whilst basic needs are defined by UNESCO as "the minimum requirements for a decent standard of life" and incorporates elements such as shelter, clothing, community services, and access to adequate food, as well as human rights, productive employment and public participation in decision-making (UNESCO, 2019).

SGI (Gløersen et al., 2016) can be categorised into non-economic services of general interest (Non-Economic Services / NSGIs), and economic services (Services of General economiclnterest / SGEI), as well as social services of general interest (SSGI). For each of the EU Member States, it can be determined on a case-by-case basis whether services will be of an economic or noneconomic character (European Anti-Poverty Network, 2007; Noguera-Tur and Martínez, 2014). The emphasis in this research is on SGEI, which is defined as "economic activities delivering overall public goods that the market could not supply without public intervention" (European Commission, 2011). The accessibility of SGI in this research is interpreted in multiple manners, since the concept of accessibility is multifaceted and includes not only physical, but also economic, temporal and socio-cultural aspects (Nared et al., 2016). An important component of accessibility is also the time dimension due to constant changes in transport hubs and connections (Kaza, 2015). The decline in the number of services in the alpine areas affects not only accessibility, but also the availability of services. Guagliardo (2014) defines availability as the number of providers of a particular service among which a user can choose within a given area. The same author also explains that spatial distance is recognized as the most obvious challenge in sparsely populated areas and rural areas, while in urban and suburban areas the key problem is time accessibility due to traffic impediments. 


\subsection{Research approach}

The results, presented in this article, derive mostly from the master thesis with the title "Analysis and spatial concept for the regional network of basic goods' supply in Idrijsko-Cerkljansko region", the work of the first author of the article (Kostanjšek, 2018), and other deliverables of the INTERREG project INTESI, to which this thesis was framed (Marot et al., 2018b, Černalogar et. al, 2017). As presented in Figure 4, the author adapted a mixed-methods approach which relies on several information inquiry techniques, including the historical analysis and a survey for residents, field survey of the empty public services buildings, good practice analysis of the supply alternatives, and strategic planning as the summarisation method to prepare the model of alternative supply. In order to obtain an insight into the past and present state of service supply in the area of Idrijsko-Cerkljansko, as well as to analyse the supply and demand, an historical analysis was carried out for three historical periods; 1900 to 1945; 1945 to 1991; 1991 to 2017. The historical analysis was supplemented by field trips and an on-site survey of former service buildings and their condition. The field survey of vacant former buildings with services included an analysis of specific features, such as the condition of buildings and visual characteristics, as well as their location, address, current use, causes of omission and current ownership, and was conducted between $24^{\text {th }}$ of July and $8^{\text {th }}$ of September 2017.

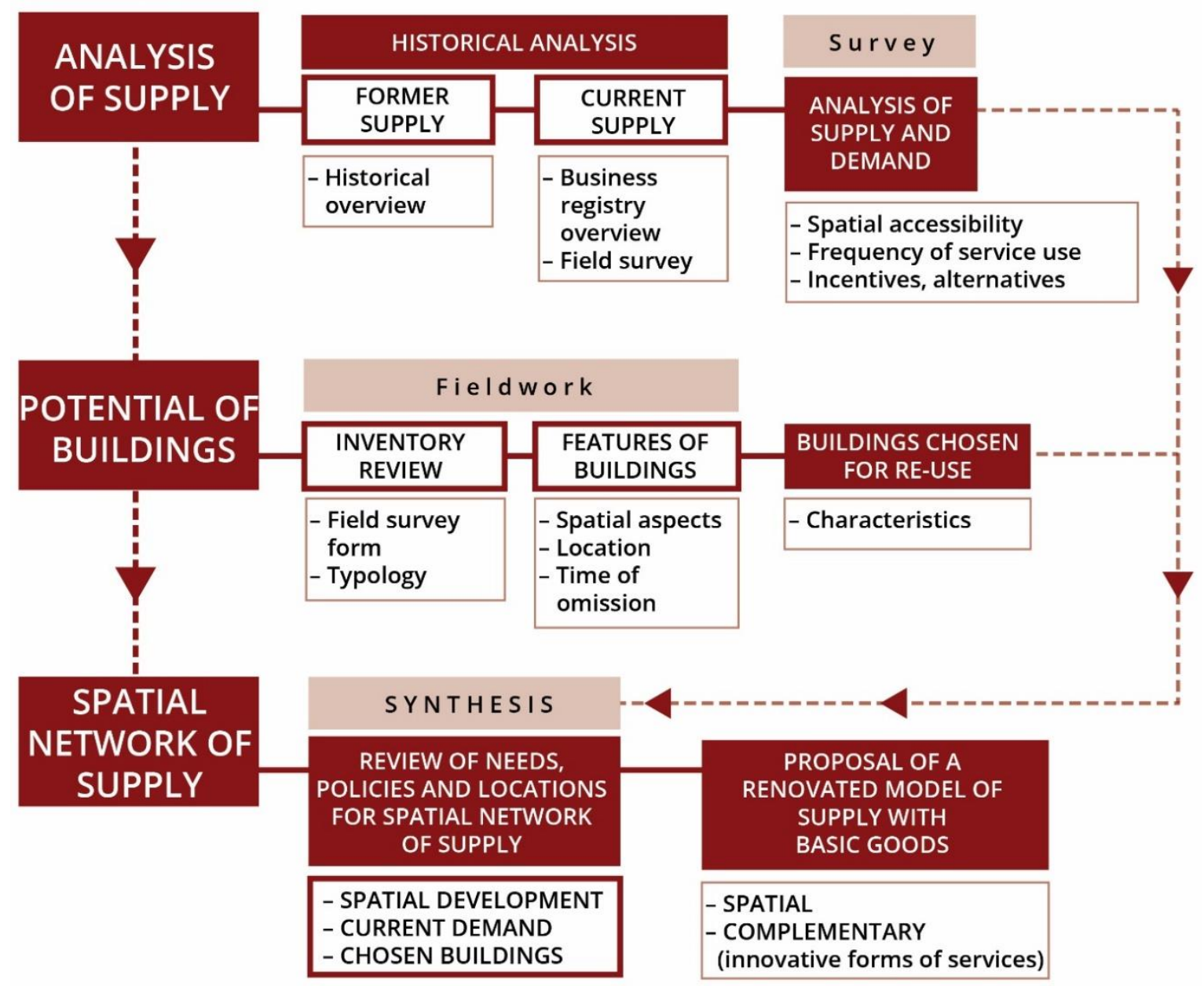

Fig 4. Visualisation of methods used in analysis of supply with basic goods and proposal of improvement. Adapted from Kostanjšek, 2018

The spatial characteristics, relocations and related dynamics of the supply of basic goods during the period 1991 and 2017 were determined by comparing the former and current state of services in the area. An analysis of current provision included a list of existing services by type (retail grocery stores, textile stores, banks, postal services, schools and so on) as registered in the national Business Register of Public Legal Records and Related Services. The register can be claimed as a very reliable resource since the findings in the field survey verified the findings 
about the location and viability of services' operation from the register. The field survey included buildings within settlements (namely in the centre of villages or towns). Remote buildings were excluded from the survey due to the conclusion that these locations were inappropriate for the restoration of village service supply functions because they are not centrally located.

For the analysis of the demand for basic goods in this study, we adapted a similar approach to the research as Mayora et al. (2018) did and conducted an online survey. The survey contained altogether 18 questions: 5 open and 13 closed questions addressing various aspects of supply and demand including meeting the needs of the inhabitants of the area, the places and frequency of the provision of services, ways of accessing and satisfying inhabitants with regards to accessibility, factors in the selection of services, needs and proposals for improving accessibility, the socio-economic data on respondents, and the extent to which the inhabitants use innovative forms of services, e.g. e-bank, e-pharmacy. The survey was carried as an on-line questionnaire. It was distributed via social networks, the website of the local development agency, and a local newspaper to reach as much population in age 18 years and above as possible.

Altogether, from July to the end of November 2017, 233 completed questionnaires were collected, which represent $1.7 \%$ of the targeted population age and $3.7 \%$ of the households in the region (absolute number was 6,227, number only available for 2018, not 2017). This random sample we can claim to be nominally representative. We can also claim for the whole population that with the level of confidence of $95 \%$, the margin level of error is $6.5 \%$ that population behaviour deviates from the sample behaviour. Of the survey participants (see Figure 5), 77\% were women, while the remaining $23 \%$ were male. As many as $59 \%$ of the answers came from Idrija, while the remaining $41 \%$ were from Cerkno. The answers in the survey were collected from 25 different settlements. The majority of respondents (36\%) lived in the town of Idrija, while $11 \%$ of the respondents came from Cerkno. The larger shares of respondents from towns (Idrija, Cerkno) confirm that the sample was representative in terms of spatial distribution of respondents.

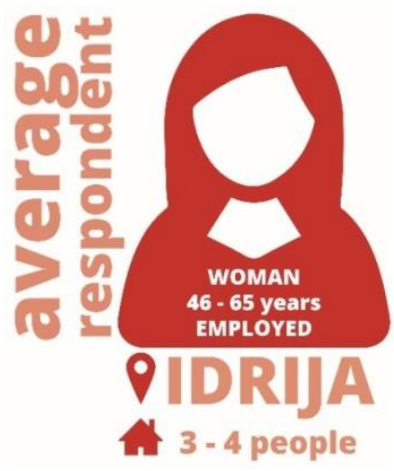

Fig 5. The average respondent in the survey. Source: Kostanjšek, 2018

As synthesis of the study the proposal of the supply model has been prepared. The main idea of the model is to supplement the existing supply network with basic goods at the regional level. The model of alternative provision of basic goods is based on the needs of the population as expressed in the survey, the selected listed buildings of former service supply and the guidelines of each of the municipalities (Idrija and Cerkno) for the supply as written in the spatial and other strategic documents.

\section{Contemporary challenges of the supply with basic goods}

\subsection{Historic supply networks}

Based on the field survey of existing service supplies, services offering basic goods were found in 7 settlements in 2017, compared to 12 settlements in 1994 (see Figure 6). The vast majority of services were located in the regional centre of Idrija. In comparison to the period between 1991 and 2017, the number of central settlements decreased from 14 to 7 . This spatial pattern confirms the results of the online survey (presented below) that current supply does not entirely meet the demands of the area's population with the exception of the respondents living in Idrija. 
According to the field survey, 24 small shops, 6 post offices, 3 primary schools, one bank and one butcher have closed in the period between 1991 and 2017 in the Idrijsko-Cerkljansko area.
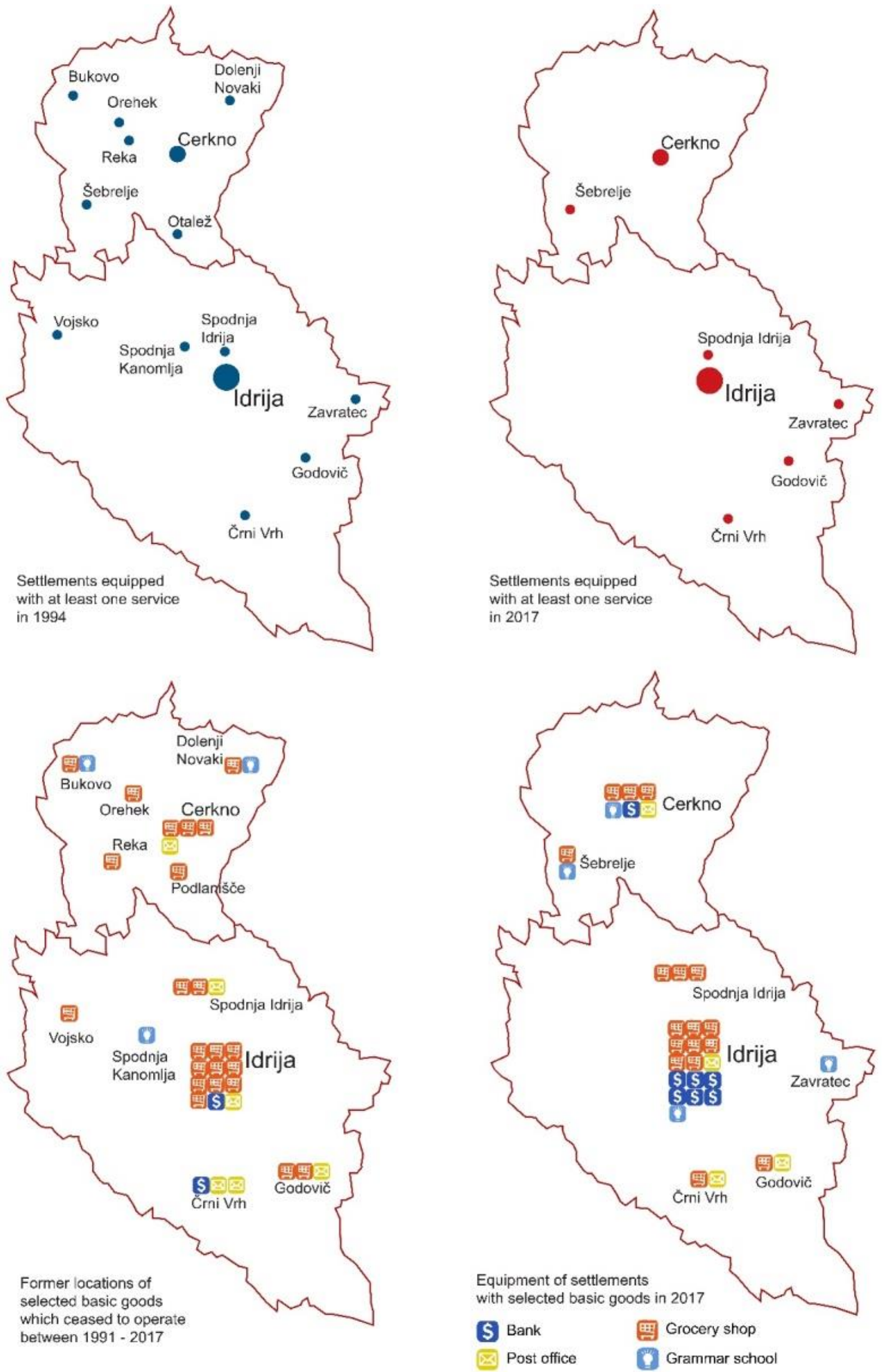

Fig 6. Settlements equipped with at least one service in Idrijsko-Cerkljansko: situation in 1994 (top left) and situation in 2017 (top right) and the former locations of selected basic goods, which are no longer in use (bottom left) and current selection of basic goods (bottom right). Source: Kostanjšek, 2018 
Altogether, 49 of former service buildings were identified, (34 of them are shown in Figure 6, the remaining 15 buildings hosted other services, such as pharmacy, butchery, bakery). A considerable share of the buildings surveyed are still in use (22\%), $47 \%$ of buildings were partly in use and $31 \%$ of the surveyed buildings were vacant. However, spatially, the buildings still in use are located in larger settlements. The majority of services were abandoned between 2010 and 2015.

The identification of the current use of the former service buildings was particularly problematic, since most buildings were found either in a state of renewal, either without cadastral record (47\%) or with unknown ownership (35\%). Most of the surveyed buildings were currently in private ownership, (45\%), with only $10 \%$ in public ownership, whilst the remaining $35 \%$ were either of mixed ownership or unknown. The field survey compared to the analysis of former services revealed that most of the surveyed buildings had previously been used as shops (43\%), post offices $(11 \%)$, or for residential $(9 \%)$ or educational purposes; grammar schools $(5 \%)$. The buildings were now used for a variety of different services, such as pubs, butchers, a bank, a fish market, a car dealership, hairdressers, a bakery, and a dairy.

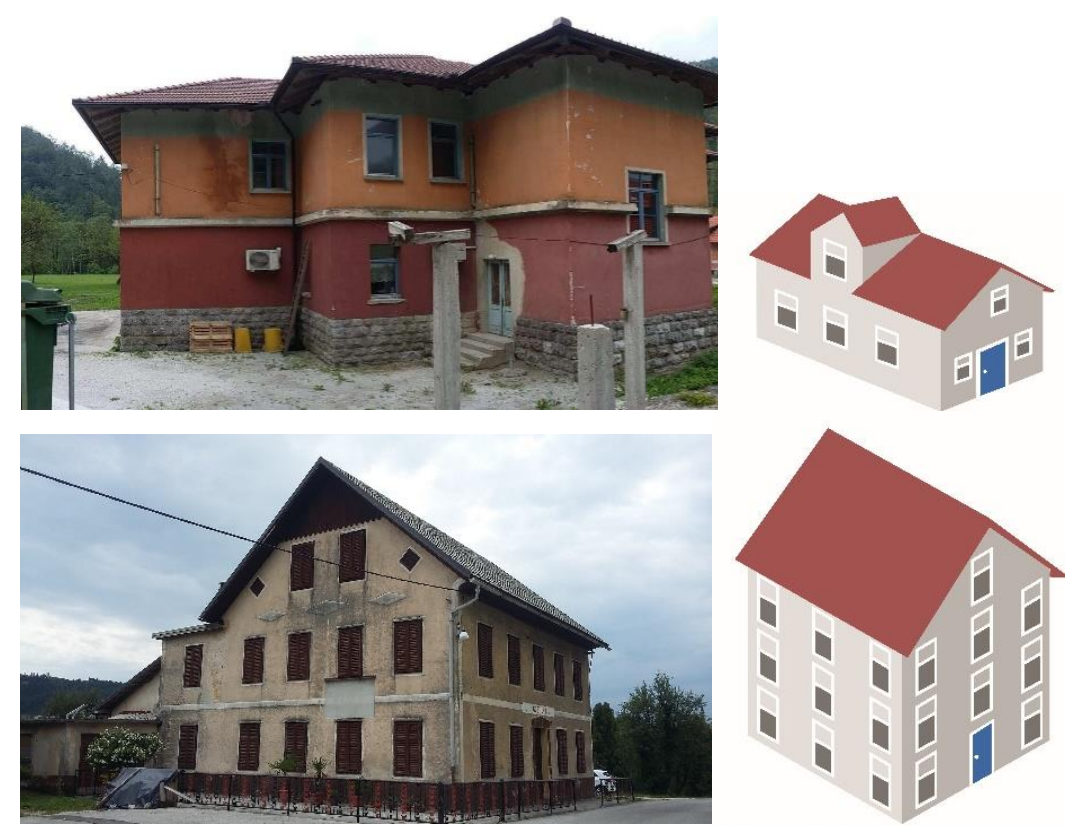

Fig 7. Two of the selected buildings and their attributed architectural types: a grammar school in Spodnja Kanomlja (above) and a former village shop in Bukovo (below). Source: Kostanjšek, 2018

The surveyed buildings were geo-located and mapped according to the types of services they provided. In order to perform a comparative analysis, only a selected sample (34 out of 49) of the most needed basic goods was mapped. The former SGI were more numerous in the rural areas as village shops operated in the centres of villages in such areas. The historical analysis revealed that from 1991 until 2017, 24 shops, 6 post offices, and 3 primary schools were closed down. The most significant impact of the services closing down was experienced in the countryside area of Cerkno - none of the five former shops exists today. Additionally, two primary schools were closed down due to an insufficient number of pupils being enrolled. The difference between the past and today is very noticeable in the historical centre of Idrija even though the number of services available in Idrija has increased. Meaning that the number of small shops in Idrija has decreased (10 were closed down), whilst large commercial centres have opened upon the city's outskirts. The provision problem also arises with the closing of two postal offices, which moved from the centres of settlements to petrol stations outside the settlements (examples of this were found in Godovič and Črni Vrh) or they were completely closed, such as in Spodnja Idrija. The centralization of services that provide basic goods is highly evident, especially when compared to the state of affairs that exists in the central settlements of the area. 


\subsection{Gap between the demand and supply}

According to the comments received by individual respondents, numerous shortcomings in the availability of services were revealed. These have been merged by topic as illustrated in Figure 8 . The issues that have been repeatedly exposed are more strongly reflected in the figure (parking, for example, was mentioned as a shortcoming by more than 30 respondents). The inhabitants are aware that their local stores are not only centres of supply but also important meeting points for social life. Despite less numerous comments regarding supply issues, some residents emphasized the problems with regard to accessing services where they live. The living environment, especially for the elderly, has changed to the point where they experience it as lifeless. There are no meeting points, no central functions, no access to goods in the villages, and villagers no longer encounter each other. Users from younger, more "mobile" age groups have also expressed experiencing similar problems but from a perspective of services (and other aspects) being accessible by car.

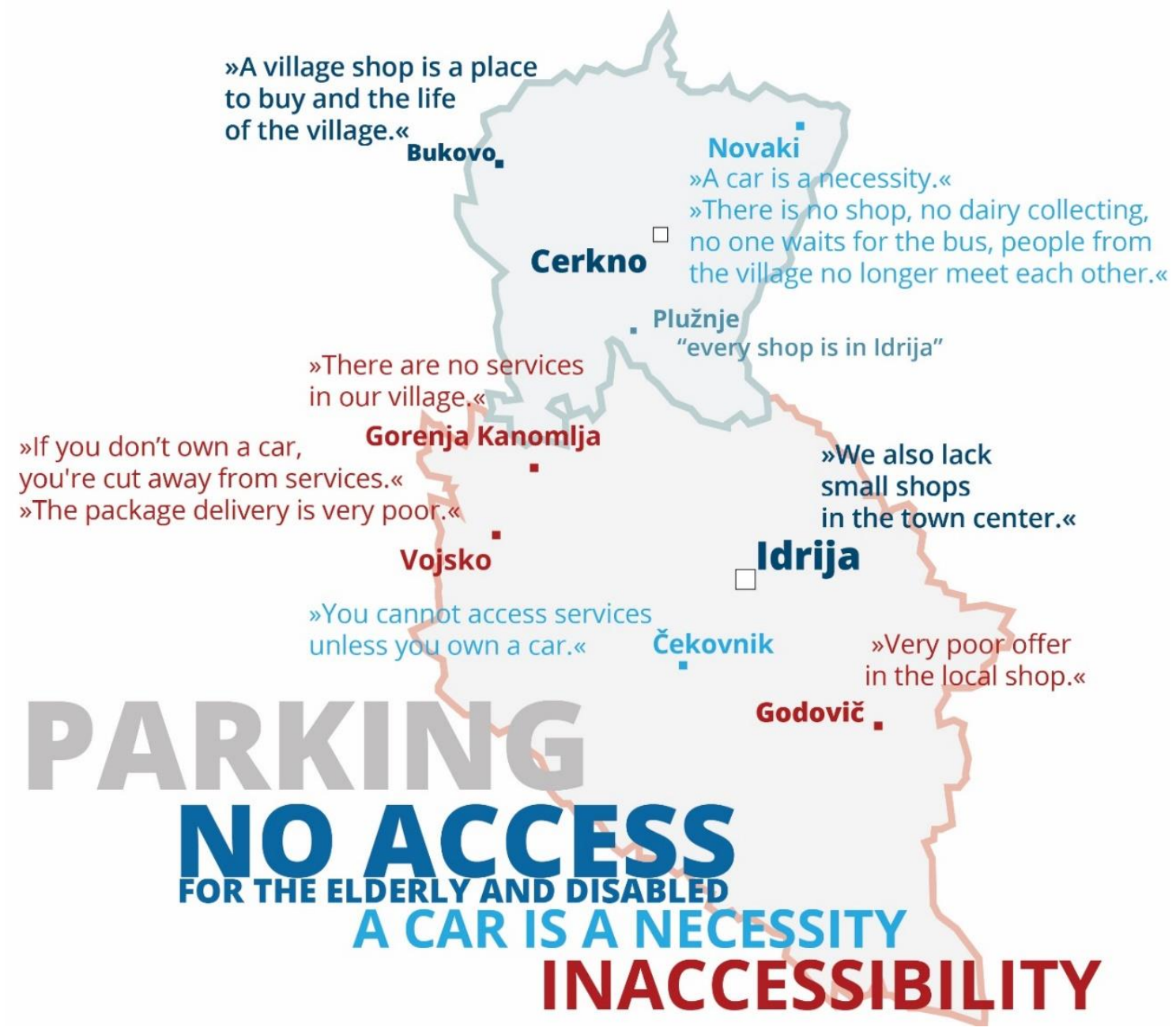

Fig 8. Exposed unmet needs and other difficulties concerning the current supply in the Idrijsko-Cerkljansko area Adapted from Kostanjšek, 2018)

The inhabitants of the Idrija-Cerkno region are not only dealing with a lack of availability of services, but also a lack of diversity in the services available. The service that is least accessible - and also possesses the lowest number of providers - is the textile shop (see Fig. 9). Inhabitants requiring textile shops must travel to larger regional centers, such as: Kranj, Nova Gorica and, above all, Ljubljana. In addition to the lack of clothing stores, residents feel that there is a lack of grocery stores, especially in rural areas and villages: Bukovo, Novaki, Vojsko. In Cerkno, there is a lack of technical equipment and a lack of stocked hardware shops, whilst in Idrija there is a lack of cosmetic shops. Bakeries, butcher shops, post offices and marketplaces, are the services most significantly missing in the countryside. 


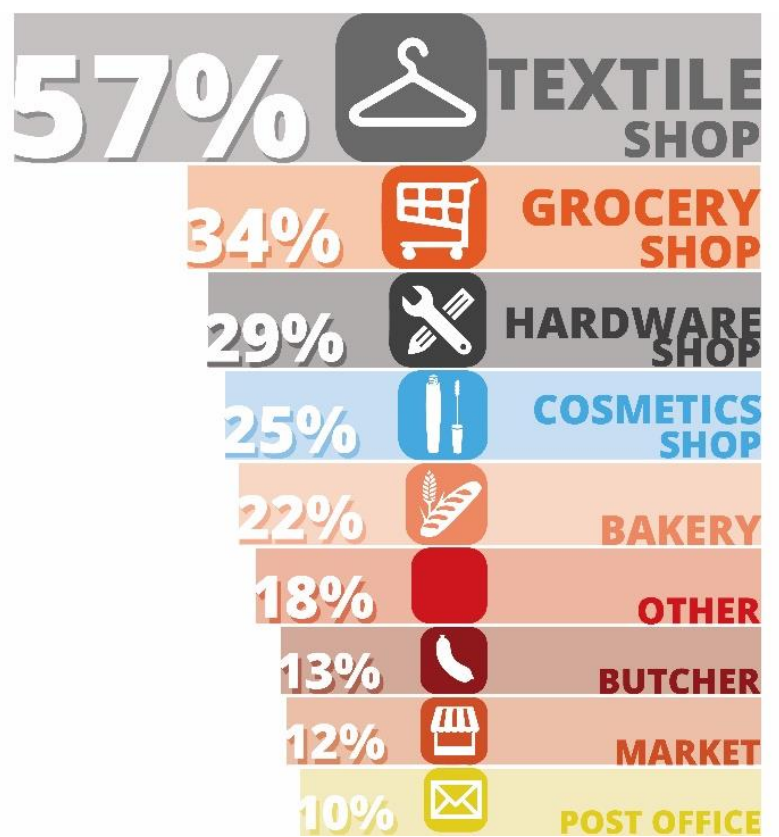

Fig 9. Services that are most needed in the Idrijsko-Cerkljansko area by shares of responses. Source: Kostanjšek, 2018

The needs and suggestions of the inhabitants are mainly expressed as suggestions to promote local, home-grown foods and other goods (21\% of respondents). In Idrija and Cerkno, there have been initiatives to improve the availability and variety of local products on the market $(17 \%)$. At the same time, it also means encouraging local producers to sell their products in local markets. According to the expressed needs, the residents proposed a more even spatial distribution of services (14\%), a fairer division of central functions between Cerkno and Idrija (11\%), and an initiative which would contribute to improved know-how of the small retailers and farmers $(6 \%)$. The remaining $31 \%$ of the respondents did not state any suggestions.

\subsection{Car-dependent accessibility to services}

According to the analysis, more people are accessing services by car. Grocery shops are usually visited more frequently than technical shops or banks. According to the frequency of using services, food shops and ATMs are at the forefront, followed by gas stations, pharmacies and post offices. Shops with more specific goods (hardware, clothing) were visited less frequently once every 6 months (see Fig. 10).

The length of users' routes to access specific service depends on how often this particular service is used. For weekly and more frequent errands, the nearby services in larger settlements within the surveyed area were used, such as Idrija or Cerkno, as well as some services in the nearby settlements of neighbouring municipalities such as: Tolmin, Logatec, Žiri and Gorenja vas. To better illustrate the issue of time accessibility, it is noted that to reach the grocery shop in Idrija, it would take, for example, more than 20 minutes $(13 \mathrm{~km})$ for a resident from Vojsko, and about 35 minutes from Bukovo (26km). The approximate time distance from Idrija to Ljubljana is between 50 and 60 minutes. To access services that are used once a month or once every six months, it is usually necessary to travel longer distances and potentially out of the region. According to the survey, users are willing to overcome such distance for the provision of various services such as textile and hardware shops including, from some less accessible areas within Idrijsko-Cerkljansko and out of the region as well (Fig. 11). The latter is due to the fact that they commute larger distances to work and thus these services are then "on the way" for them. 


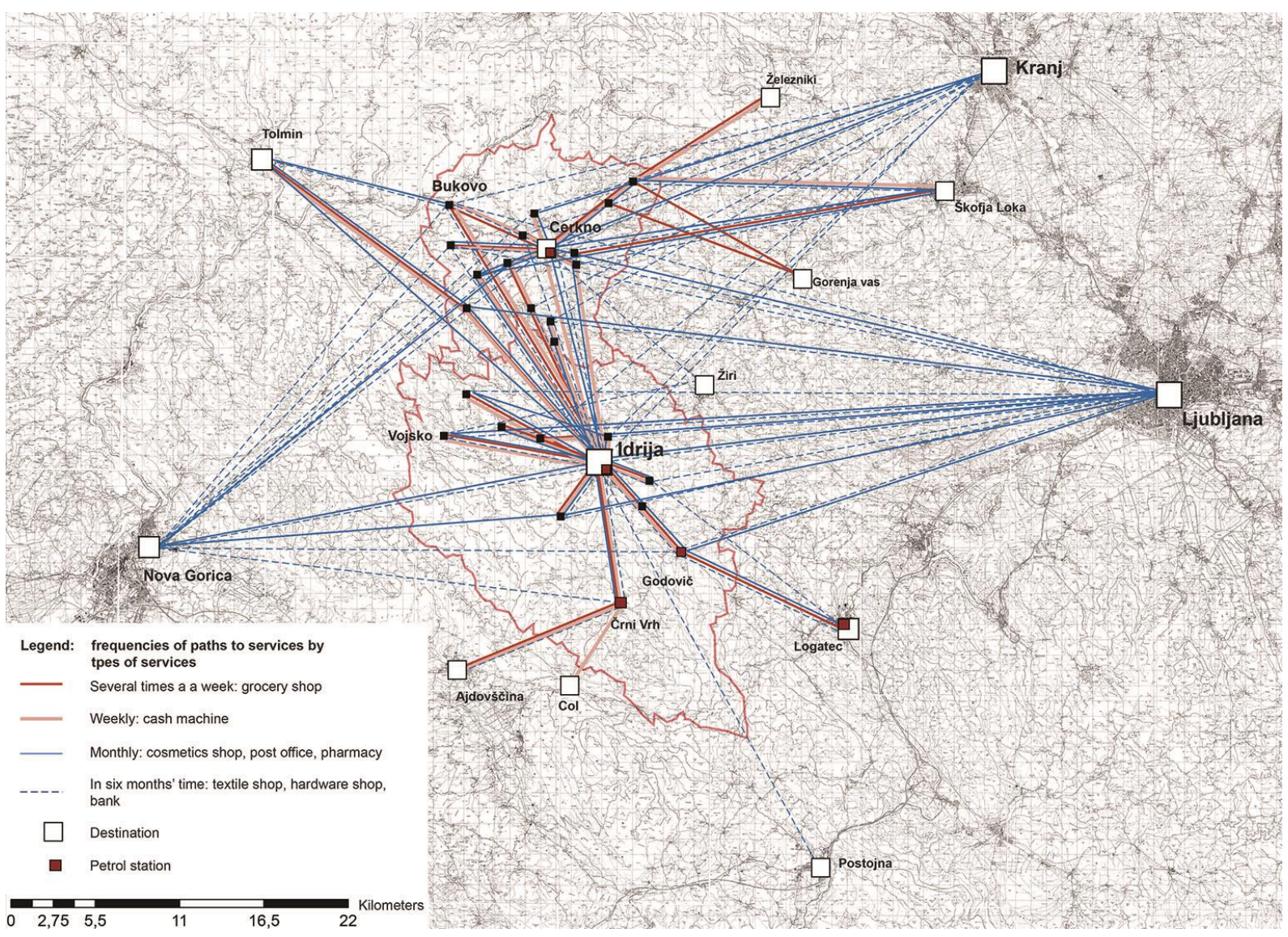

Fig 10. Accessibility to selected services by frequencies of use including locations of used services. Source: Kostanjšek, 2018

Although services are accessible almost exclusively by car, the residents, however, do not prioritize accessibility as an important decision making factor on where to shop. Of all the foreseeable factors, it appears that the factors directly related to accessibility of services (e. g. proximity to the residence, the possibility of parking) are of lesser importance than the quality of service. The three main decision factors which are used to select individual services to access, ranked from 1 to 5 with highest importance (5), are quality (46\%), price (35\%) and the selection of products available (41\%). Parking was selected as very important by $41 \%$ respondents, while proximity to their places of residence was only important to $24 \%$ of respondents.

\subsection{Emergence of e-services}

It is predicted that by 2025 , nearly $20 \%$ of retail businesses will operate through on-line channels, with global on-line retail sales reaching more than 4 trillion euros (Kotler, 1998; Ervasti et al., 2014). Digitalisation itself has caused a shift from product based to service based businesses, with consumers increasingly shopping on-line for better prices. There is very little opportunity for brick-and-mortar shops to be as competitive as online retail platforms (Hänninen et al., 2017; Jiang et al., 2011).

Despite the generally positive trend of using e-services and other alternative supply models, the findings of our survey suggest that alternative forms of services are not used very often (Kostanjšek and Marot, 2018). The area's broadband internet connection is steadily being improved with optical fibre (Telekom Slovenije, 2019), however, the reason for the current state of (non) use of e-services is the high proportion of elderly residents $-21.8 \%$ in the municipality of Idrija and $19.8 \%$ in the municipality of Cerkno (Giuliani et al., 2017a). The elderly usually does not know enough of contemporary digital services to use them. It is also the case that many people prefer to be served in real time rather than online so that they may also partake of, for instance, conversations with a neighbour whilst visiting a physical bricks and mortar shop (Kostanjšek, 2018; Ervasti et al., 2014). According to the survey, residents used online shops and 
online banks only about once every six months (see Fig 11). Similarly, an Italian survey on innovative services concluded that people shop online for clothing, electronics and editorial products from 1 to 4 times a year (Ghajargar et al., 2016). Other online services are generally not used or even unknown by residents (see Fig 11). Among other alternative ways of providing services, residents are most likely to go shopping monthly in a local cooperative, or to purchase from producers directly, or to use a mobile shop which visits every settlement about once every fortnight.

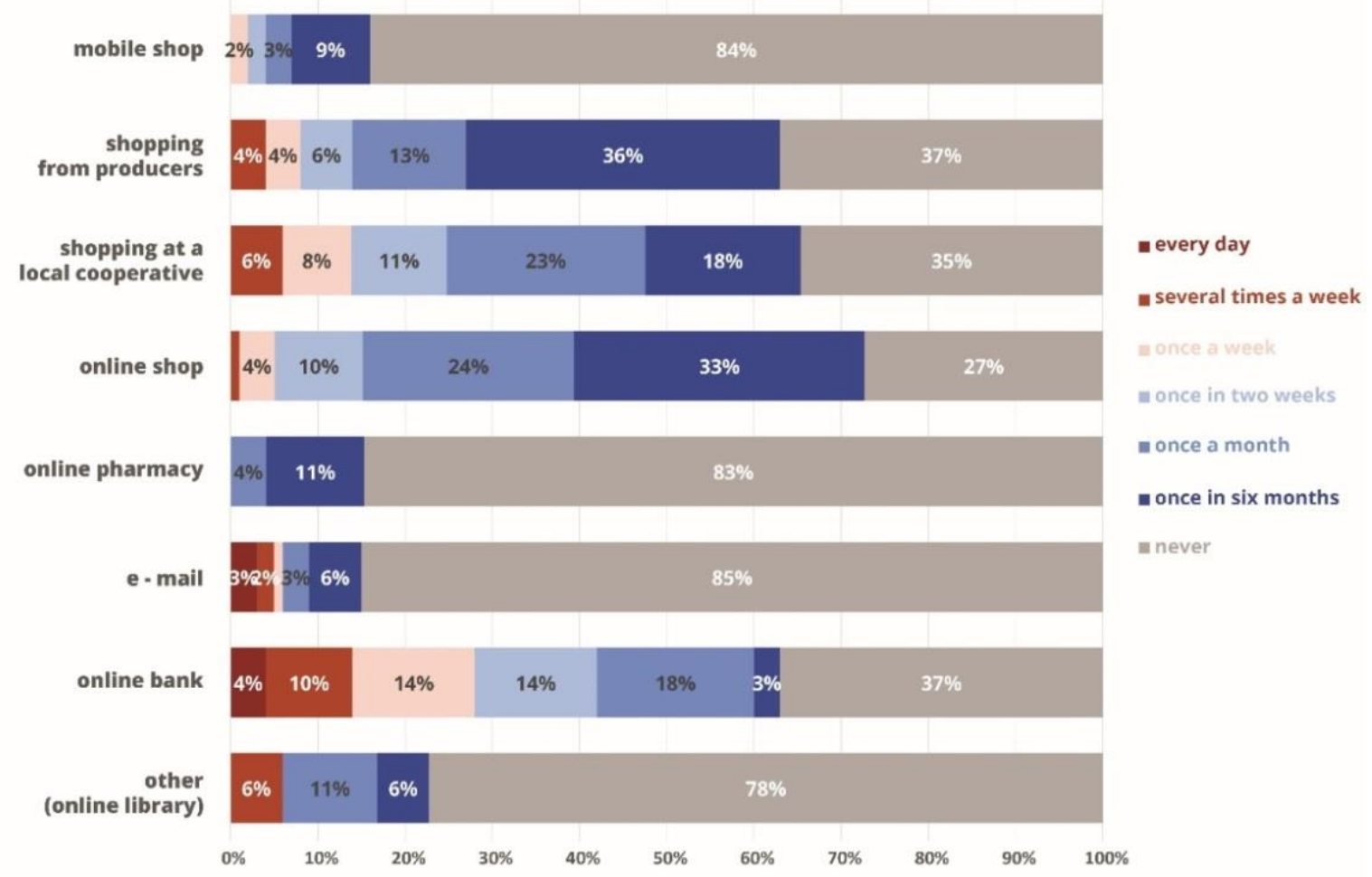

Fig 11. Frequency of using alternative forms of services by shares. Source: Kostanjšek, 2018

\section{Alternatives}

The state of today's provision of services along with the development of means of delivering them requires reflection and innovation. As part of our investigation, a range of relevant good practices were examined. Furthermore, based on the knowledge gathered in the project, we have prepared a model of the alternative supply of the basic goods for the inspected region of IdrijskoCerkljansko.

\subsection{Good practice analysis}

According to Bogan and English (1994), good practice is a method, process or model which has been proven effective in solving problems and which could be reused on another location under certain conditions. Marot et al.'s (2018b) analysis of good practices put an emphasis on searching for new models of service management and e-services. The main source were the former transnational projects within the Alpine Space Programme for the geographical context, other relevant internet sources, press releases and researchers' knowledge of the field (Antonioni et al., 2017; Egger et al., 2011; Swiss Working Group for Mountain Areas, 2007). Altogether 8 projects from the Alpine Space Programme were examined, one from the Central Europe programme, one Horizon2020 project, and one Slovenian project. 11 examples of good practice in the field of the supply of basic goods were identified (Table 1). These can be divided into four types: 1 ) online shops (three cases), 2) new models of management of the retail sector (6 examples), 3) linking producers and shops (3 cases), and 4) loyalty programs (one example). Some examples of new management models were developed as pilot projects such as the delivery of goods within 
the PUSEMOR project (Swiss Working Group for Mountain Areas, 2007), where a delivery system was organized with customers ordering what they needed by telephone. Practice of Post partner attempted to solve the problem of an inefficient postal network in Austria (Egger et al., 2011). The Carinthian government and the Austrian post service arranged new locations for postal offices within other retail providers. As an example of a new management model, the Slovenian Fama Cooperative (Fama, 2018) is engaged in the supply of local food and crops to many farms in the countryside, and in the long run, the cooperative aims to create a group of products under a common brand name.

Tab 1. Good practices identified by types in the field of basic goods.

\begin{tabular}{|l|l|}
\hline BASIC GOODS & GOOD PRACTICE [within a project] \\
\hline Online shops & $\begin{array}{l}\text { Zeleni zabojček - delivery of local food } \\
\text { 'Wolfgang Bringt's' - daily food supply through the online platform } \\
\text { [Access project] } \\
\text { E-services in mountain areas- »AMICO WEB» (»WEB FRIEND«) } \\
\text { [Qualima project] }\end{array}$ \\
\hline New models of management & $\begin{array}{l}\text { Cooperative Fama } \\
\text { Post partner - cooperation with shops in rural areas [Access } \\
\text { project] } \\
\text { Delivery of goods for everyday needs [Pusemor project] } \\
\text { Multi-purpose enterprises [Qualima project] } \\
\text { Improving the network of small providers [Access project] } \\
\text { Support for smaller shops in villages [Access project] }\end{array}$ \\
\hline $\begin{array}{l}\text { Linking producers and } \\
\text { shops }\end{array}$ & $\begin{array}{l}\text { Catalogue of local food producers [Demochange project] } \\
\text { Loyalty programs }\end{array}$ \\
\hline
\end{tabular}

In the field of online retail in Slovenia, an online shop of organic fruits and vegetables Green Box ("Zeleni zabojček") delivers organically-produced fruits and vegetables to subscribers. Delivery is possible only to certain locations in Slovenia on certain days. Seasonally-produced food is delivered directly from growers to buyers. The service can be implemented in any region, but there must be a sufficient amount of providers (Zeleni zabojček, 2018). A similar good practice was carried out within the Access project in Baden-Württemberg, Germany (Egger et al., 2011). The delivery system covered the offer of eight local stores, and orders were placed either online or by telephone. Delivery, ordering and transport of goods were organized by home care services and municipal Caritas. 


\subsection{Innovative supply model for the basic goods}

In order to improve the spatial accessibility of services in Idrijsko-Cerkljansko, a model of suggestions to alter the existing network of services have been developed. They comprise of the identified dilapidated former service buildings, which are 1) located within former central settlements (Fig. 6) or 2) within settlements with existing initiatives for improvements. The model takes into account municipal spatial guidelines for the development of central settlement networks in the area, both of Cerkno (2013) and Idrija (2011). The proposal also included analysed examples of good practice, presented in chapter 5.1, such as online food delivery systems.

The proposed supply model as an alteration of existing supply network in the region is based on three key criteria 1) locations of available former service buildings, 2) services needed, expressed by respondents, and 3) municipal ordinances on central settlements. The highest importance is put on the second criteria, since the demand for services is the key to maintain their profitability. Depending on the residents', each of the central settlements, foreseen by the municipal ordinances, is assigned the corresponding services. The proposed supplementary services are allocated to settlements through three key mechanisms (Fig. 12, blue section), namely: 1) the integration of producers into the food supply chain, 2) increasing the existing offer of products, and 3) clustering services according to demand. By using these mechanisms, the application of direct measures (cooperatives, markets, mixed use, digital services, online shop and delivery) are planned to be applied to supplement the current supply of basic goods. Moreover, after the taken measures are implemented successfully, the long-term impacts on the Idrijsko-Cerkljansko area are foreseen, which will be manifested as 1) efficient use of space and recovery of settlements, 2) integration into the system of central places, and 3) more balanced development of the area (see Fig. 12).

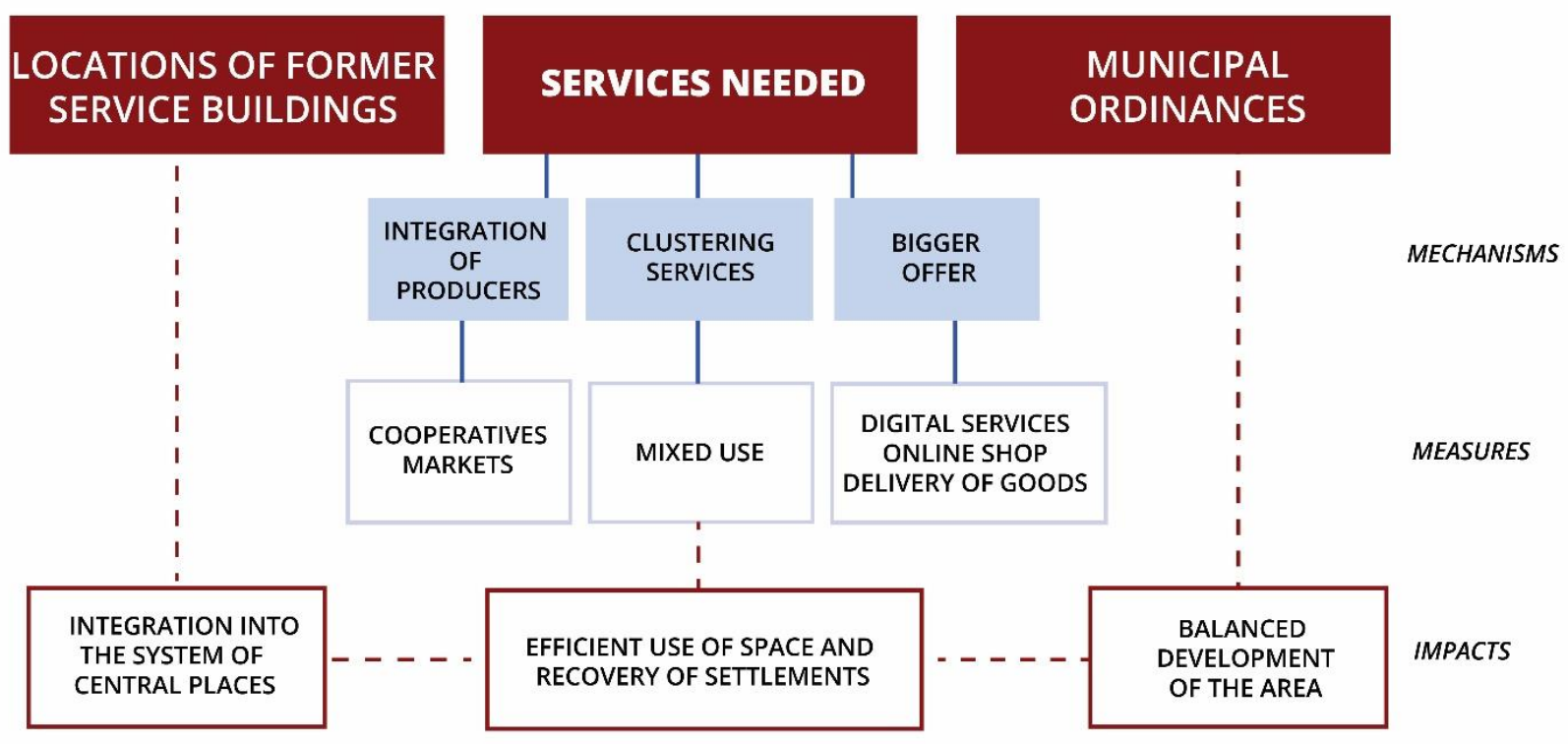

Fig 12. The principle of designing a renewed model of basic goods supply. Author: Barbara Kostanjšek 


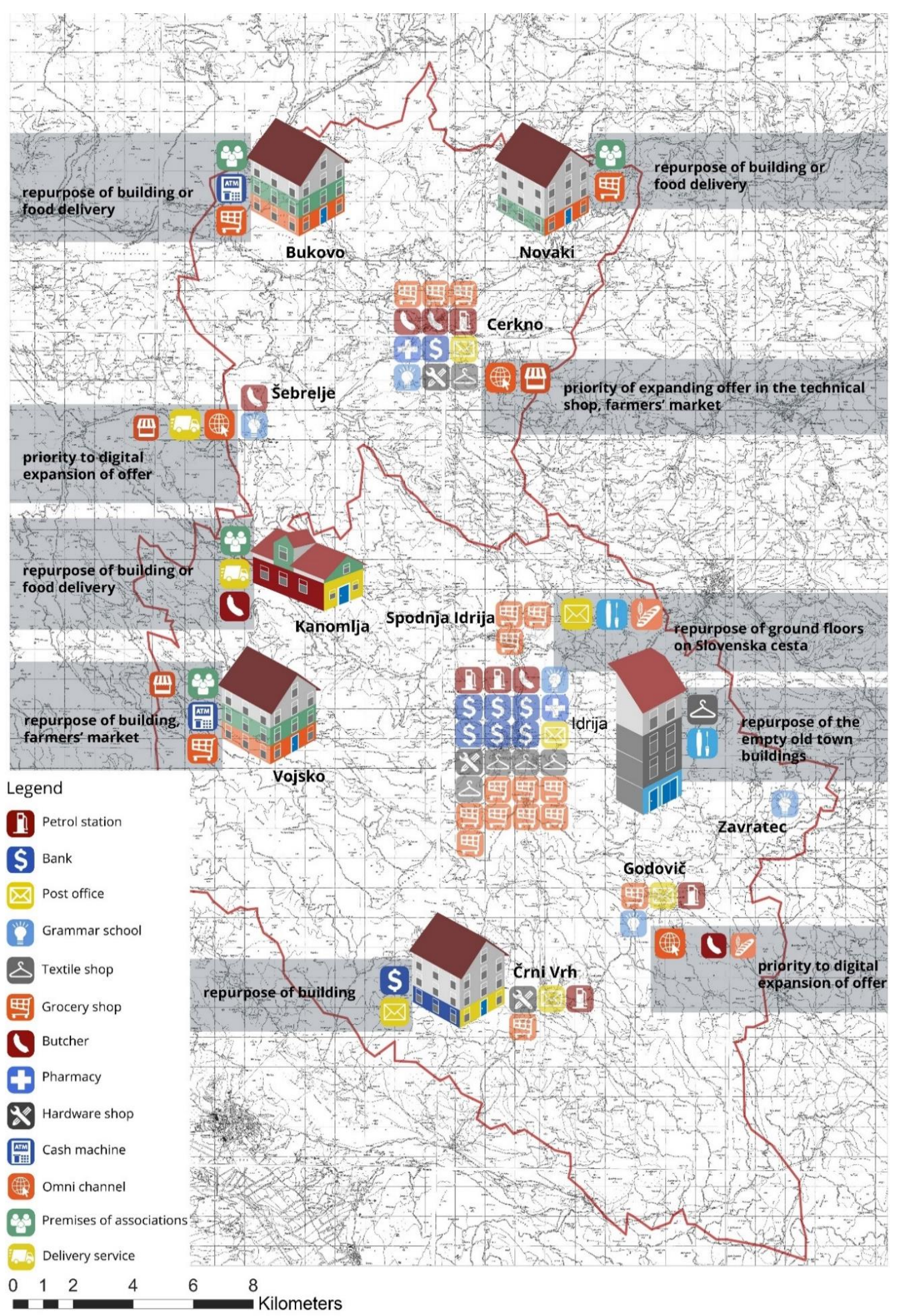

Fig 13. Proposition of a renewed spatial model of the supply of basic goods including current demand, spatial guidelines for supply centres and selected former supply facilities. Source: Kostanjšek, 2018 
The integration of farmers into the supply chain of basic goods as one of the key mechanisms to apply measures represents the solution in the Vojsko, Kanomlja, Bukovo and Novaki. Integrating farmers and producers into the supply chain is also linked, where possible, to the reopening of village shops or, at least, to the organized delivery of food. In the settlements of Godovič, Cerkno, Šebrelje and Spodnja Idrija, it is proposed to increase the volume of supply and its diversity. In the rural hinterland of Cerkno, services need to be re-established as the impact of centralization has been even stronger. The three main measures are reasonably distributed across the IdrijskoCerkljansko region (see Fig. 12 and Fig. 13). The proposed measures (markets, cooperatives, mixed use of services in one building, digital services, delivery) are applied to the settlements according to the proposed model by reusing selected buildings. The re-use of the selected buildings attempts to re-establish the former function of a central place with services to village settlements wherever possible. The buildings proposed for mixed use of services are coloured with different colours (Fig. 13).

The proposed model takes on all possible supplements and updates of the existing basic goods spatial supply system in the best scenario in which the village nodes and intersections will be restored upon the introduction of the three key measures as the revitalization of settlements with services.

\section{Discussion with conclusion}

The research within this paper analysed the past and present supply and current demand for SGI in Idrijsko-Cerkljansko area using mixed methods approach and proposed possible solutions to improve the existing network of SGI supply in the area. This study found that most former services had ceased within the last 20 years. In the rural area of Cerkno, for example, all of the former village shops (5) are now abandoned.

After the assessment of past and present supply of basic goods and the spatial characteristics of the location of services, the centralisation trend was highly evident in the regional centre of Idrija. The closing of service activities, notably in rural areas, affects not only the development and quality of life, but also the image, evaluation and the identity of those places (Benkovič Krašovec, 2006; Kostanjšek, 2018). It represents a visual and functional degradation of traditional rural landscape with specific settlement heritage.

As the online survey results have shown, the expectations of residents in the region with regards to the supply of basic goods are low. They are willing to drive by car to the "not so nearby" shop. Car dependency can, to some extent, be explained via reference to Slovene "driving-everywhereby-car" culture, mostly due to the poor state of the public transport especially in remote areas. Furthermore, the residents claimed that finding a parking space presents one of the key challenges while shopping for basic goods. Shopping patterns for specific or less frequent needs confirmed the hypothesis that consumers are used to travelling further to obtain such products. It was also noted that the elderly are largely dependent on their families, neighbours or alternative means of transport such as taxis or transportation provided by volunteers (a service called Sopotnik).

Distance to the specific service and its location were not recognised as an important factor of choice. Instead, the survey results confirmed that best value was the most important factor when purchasing a product, which is in line with the findings of Hänninen et al. (2017). The main factor of selecting a specific service was the quality of service $(46 \%$ of respondents marked it as highly important), the price of the service (51\% consider it as important) and the variety of products on offer (45\% marked it as important). These results suggest that users are more focused on getting as many quality goods or services as possible for the best possible price. The economic accessibility has been rated as the most characteristic value of a service, also according to Ghajargar et al. (2016), but it is not clear whether the users would be willing to pay more in order to achieve better quality of service. The participants also claimed that availability of local products should be higher. These products, as residents stated, could be provided via local markets or through improved informing as to how to obtain the food products directly from the producers. 
The survey showed that alternative solutions such as mobile grocery stores and e-services were less used, due to inhabitant's preference towards physical services. This contradicts the naive approach of providers who introduce a digital version of a service to replace the place-based one without consulting customers beforehand. Some e-services solutions can be very innovative and user-friendly in terms of integrating several services and enhancing information made available. However, confusion with using e-services occurs especially amongst older people who are mostly not skilled in the use of technology (Marot et al., 2018ab; Giuliani et al., 2017a; Marot and Kostanjšek, 2018). Thus, more efficient e-services policies need to be developed involving all stakeholders (Harfouche and Kalika, 2009).

In addition, participants revealed further limitations of e-supply in remote area, with poor internet connections being the main disadvantage. This is a particular problem in alpine areas given their topography. The geomorphology of hilly areas is also a practical limitation for physical delivery services, since the delivery of on-line ordered goods is not done to the address of the person who ordered a product, but to a distant location in the nearest central town. Consequently, the value of the e-service is diminished. According to Sept (2020) digital competences, innovative e- services and new ways of organizing rural communities must play a greater role in future rural development.

Based on these facts, the proposed place-based model took into account local characteristics, the current situation and the willingness of local populations to use the alternative means of supply. By creating the village supply centre, not only goods and services but also the missing social functions associated with face to face shopping would be provided. The discussion with the representatives of the regional development agency and the municipalities revealed that such a model could only be realised in practice if there was a financial incentive available either by the municipality or from the economically strong companies located in the region. The national Rural Development Programme 2014-2020 (2020) with its "Measure 7: Basic services and village renewal in rural areas", can present an adequate solution from which the village supply centre could be supported. Supporting local centres could improve the quality of life in the region and could be promoted as a socially responsible action. In addition, the Italian example of the energybased co-operative proved that grocery stores do not present a profit in remote areas, though they did contribute to improvements in quality of life. Furthermore, an alternative model of the goods' provision is easier to implement if the partially used or even neglected buildings are in municipal possession, since they can be reactivated with fewer resources.

In conclusion, future models for the supply of basic goods in remote hilly areas should be tailored individually to each region - a place-based approach should be applied - based on the availability of properties, the economic welfare of the given region, the age structure of its population, the social needs of its inhabitants, and the demands of residents for the basic goods. The models of supply should integrate the following elements: the provision of various goods, the means of supply (e-services and physically present services), use of neglected publicly owned buildings and the availability of the products in the local area. In such a way we believe the retail sector could contribute positively to demographic and structural change in remote hilly areas.

\section{Acknowledgements}

This paper is based on a research carried out within a pilot activity in the second work package of ASP 356 Interreg Alpine Space project INTESI - Integrated Territorial Strategies for Services of General Interest. The authors are thankful to the INTESI project partners, participants in the online and field survey and ICRA d.o.o. - the local development agency - for their engagement and productive cooperation in carrying out the project's activities. 
[1] Antonioni, S., Mion, L., Keller, M. \& Bersier, J. (2017). Good Practice Report: [Deliverable D T2.3.1]. Trento: Trentino Innovation Hub.

[2] Arcelus, F. J., Arocena, P., Cabasés, F. \& Pascual, P. (2015). On the cost-efficiency of service delivery in small municipalities. Regional studies, 49(9), 1469-1480, DOI: 10.1080/00343404.2013.837872.

[3] Barata-Salgueiro, T. \& Erkip, F. (2014). Retail planning and urban resilience - An introduction to the special issue. Cities, 36, 107-111, DOI: 10.1016/j.cities.2013.01.007.

[4] Bausch, T., Koch, M. \& Veser, A., eds. (2014). Coping with demographic change in the alpine regions: Actions and strategies for spatial and regional development (23rd ed.). Berlin, Heidelberg: Springer.

[5] Benkovič Krašovec, M. (2006). Centralna naselja na podeželju v Sloveniji. Geografski obzornik, 53(3), 10-18.

[6] Bogan, C. E. \& English, M. J. (1994). Benchmarking for best practices: winning through innovative adaptation. New York: McGraw-Hill.

[7] Christoffersen, H. \& Bo Larsen, K. (2007). Economies of scale in Danish municipalities: Expenditure effects versus quality effects. Local Government Studies, 33(1), 77-95, DOI: 10.1080/03003930601081283.

[8] Delage, M., Baudet-Michel, S., Fol, S., Buhnik, S., Commenges, H. \& Vallée, J. (2020). Retail decline in France's small and medium-sized cities over four decades. Evidences from a multilevel analysis. Cities, 104, 102790. DOI: 10.1016/j.cities.2020.102790.

[9] Egger, T., Niederer, P., Falempin, L., Becker, C. \& Stephan, C. (2011). Strategies to improve accessibility to SGI in rural mountain areas. [Interreg IVB ACCESS project report]. Bern: Schweizerische Arbeitsgemeinschaft für die Berggebiete.

[10] Ervasti, M., Isomursu, M. \& Mäkelä, S. M. (2014). Enriching everyday experience with a digital service. In The 27th Bled eConference eEcosystems Proceedings, Research Volume (not paged). University of Maribor.

[11] Ghajargar, M., Zenezini, G. \& Montanaro, T. (2016). Home delivery services: innovations and emerging needs. IFAC-PapersOnLine, 49(12), 1371-1376. DOI: 10.1016/j.ifacol.2016.07.755.

[12] Giuliani, C., Hoffmann, C. \& Laner, P. (2017a). Assessment regional report: Synthesis Report [Deliverable 3.7.2]. Bolzano: EURAC Research.

[13] Giuliani, C., Hoffmann, C., Laner, P., Černič Mali, B., Kolarič, Š. \& Kostanjšek, B. (2017b). Assessment regional report: Idrija and Cerkno - Slovenija [Deliverable 3.7.2], Bolzano: EURAC Research.

[14] Gløersen, E., Drăgulin, M., Haarich, S., Zillmer, S., Holstein, F., Lüer, C. \& Hans, S. (2016). Research for REGI Committee- Services of General Interest in the Funding Period 20142020 [research study]. Brussels: European Parliament, Directorate-General for Internal Policies.

[15] Guagliardo, M. F. (2014). Spatial accessibility of primary care: concepts, methods and challenges. International Journal of Health Geographics, 3, Art. 3. DOI: 10.1186/1476-072X3-3.

[16] Hänninen, M., Smedlund, A. \& Mitronen, L. (2017). Digitalization in retailing: multi-sided platforms as drivers of industry transformation. Baltic Journal of Management, 13(2), 152168, DOI: 10.1108-/BJM-04-2017-0109.

[17] Harfouche, A. \& Kalika, M. (2009). Challenges to Increase Government e-Services Take-Up in Lebanon. MCIS 2009 Proceedings (Art. 27). Atlanta, GA: Association of Information Systems. 
[18] Humer, A. \& Palma, P. (2013). The provision of Services of General Interest in Europe: regional indices and types explained by socio-economic and territorial conditions. Europa XXI, 23(1), pp. 85-104. DOI: 10.7163/Eu21.2013.23.5.

[19] Jiang, B., Jerath, K. \& Srinivasan, K. (2011). Firm strategies in the "Mid Tail" of platformbased retailing. Marketing Science, 30(5), pp. 757-775. DOI: 10.2139/ssrn.1633150.

[20] Kaza, N. (2015). Time dependant accessibility. Journal of Urban Management, 4(1), pp. $24-$ 39. DOI: 10.1016/j.jum.2015.06.001.

[21] Kostanjšek, B. (2018). Analiza in zasnova regionalne mreže oskrbe z osnovnimi dobrinami na območju Idrijsko-Cerkljanskega [Mag. Thesis]. Ljubljana: University of Ljubljana.

[22] Kostanjšek, B. \& Marot, N. (2018). Analiza povpraševanja po storitvah splošnega gospodarskega pomena na območju občin Idrija in Cerkno. Ljubljana: University of Ljubljana.

[23] Kotler, P. (1998). Trženjsko upravljanje. Analiza, načrtovanje, izvajanje in nadzor. Ljubljana: Slovenska knjiga.

[24] Marot, N., Gantar, D. \& Černič Mali, B. (2015). Added value from European Territorial Cooperation: the impact of demographic change in the Alps on the young. Bulletin of Geography. Socio-economic Series, 30, 87-108. DOI: 10.1515/bog-2015-0037.

[25] Marot, N. \& Damjanovič, V. (2016). WP-T1. Deliverable 2.2.2 [Report on transnational workshop]. Ljubljana: Biotechnical Faculty.

[26] Marot, N., Černič Mali, B., Kolarič, Š., Kostanjšek, B. \& Laner, P. (2018a). Izzivi zagotavljanja storitev splošnega pomena v 21. stoletju: celostnim pristopom naproti. Ljubljana: Biotechnical Faculty.

[27] Marot, N., Kolarič, Š., Černič Mali, B. \& Kostanjšek, B. (2018b). WP-T2. Deliverable 2.4.2, Pilot activities implementation - Idrijsko-Cerkljansko. [research report]. Ljubljana: University of Ljubljana.

[28] Marušič, J., Jančič, M., Hladnik, J., Kravanja, N., Kolšek, A., Piano, S., Simič, M., Maligoj, T. \& Jug, M. (1998). Krajine predalpske regije. Ljubljana: Ministry of the Environment and Spatial Planning.

[29] Mayora, C., Kitutu, F., Kandala, N., Ekirapa-Kiracho, E., Peterson, S. \& Wamani, H. (2018). Private retail drug shops: what they are, how they operate, and implications for health care delivery in rural Uganda. BMC Health Services Research, 18, Art. 532. DOI: 10.1186/s12913-018-3343-z.

[30] Myrdal, G. (1957). Economic Theory and Underdeveloped Regions. London: Gerald Duckworth.

[31] Nared, J., Bole, D., Breg Valjavec, M., Ciglič, R., Černič Istenič, M., Goluža, M., Kozina, J., Lapuh, L., Razpotnik Visković, N., Repolusk, P., Rus, P. \& Tiran, J. (2016). Policentrično omrežje središč in dostopnost prebivalstva do storitev splošnega in splošnega gospodarskega pomena: končno poročilo. Ljubljana: Anton Melik Geographical Center, Scientific Research Center of the Slovenian Academy of Sciences and Arts.

[32] Nared, J., Bole, D., Breg Valjavec, M., Ciglič, R., Goluža, M., Kozina, J., Razpotnik Visković, N., Repolusk, P., Rus, P., Tiran, J. \& Černič Istenič, M. (2017). Central settlements in Slovenia in 2016. Acta geographica Slovenica, 57(2), 7-32, DOI: 10.3986/AGS.4606.

[33] Nieto Masot, A. \& Alonso, G. (2015). Research on the accessibility to health and educational services in the rural areas in Extremadura. European Countryside, 7(1), 57-67. DOI: 10.1515/euco-2015-0004.

[34] Noguera-Tur, J. \& Martinez, A. F. (2014). Accessibility and provision of services of general interest in rural areas of the european union: an analysis of the Eurobarometer. Boletin de la Asociacion de Geografos Espanoles, 64, 489-493. 
[35] Page, N., Langford, M. \& Higgs, G. (2018). An evaluation of alternative measures of accessibility for investigating potential 'deprivation amplification' in service provision. Applied Geography, 95, 19-33, DOI: 10.1016/j.apgeog.2018.04.003.

[36] Perko, D. (1998). Regionalizacija Slovenije. Geografski zbornik, 38(1), 11-57.

[37] Rauhut, D., Marques da Costa, E. M. \& Humer, A. (2013). SeGI. Indicators and perspectives for services of general interest in territorial cohesion and development - [Final Report]. Luxembourg: ESPON EGTC.

[38] Sept, A. (2020). Thinking Together Digitalization and Social Innovation in Rural Areas: An Exploration of Rural Digitalization Projects in Germany. European Countryside, 12(2), 193208. DOI: 10.2478/euco-2020-0011.

[39] Syssner, J. \& Meijer, M. (2017). Informal Planning in Depopulating Rural Areas. European Countryside, 9(3), 458-472. DOI: 10.1515/euco-2017-0027.

[40] Teller, C., Wood, S. \& Floh, A. (2016). Adaptive resilience and the competition between retail and service agglomeration formats: an international perspective. Journal of Marketing Management, 32(17-18), 1537-1561. DOI: 10.1080/0267257X.2016.1240705.

[41] Twardzik, M. \& Heffner, K. (2019). Small Towns and Rural Areas - as a Prospective Place of Modern Retail Trade Formats in Poland. European Countryside, 11(1), 74-84. DOI: 10.2478/euco-2019-0005.

[42] Van Meeteren, M. \& Poorthuis, A. (2017). Christaller and "big data": recalibrating central place theory via the geoweb. Urban Geography, 39(1), 122-148. DOI: 10.1080/02723638.2017.1298017.

\section{Other sources}

[43] Černalogar, D., Lazar, J., Bizjak, M. \& Gantar, D. (2017). Poročilo št. 2 - Poročilo o izvedbi načrtovanih aktivnosti do junija 2017 in predlog izvedbe nadaljnjih načrtovanih aktivnosti na Idrijsko-Cerkljanskem. Idrija: Idrijsko-Cerkljanska razvojna agencija.

[44] ESPON (2013). SeGI Indicators and perspectives for services of general interest in territorial cohesion and development. Applied Research 2013/1/16.Final Report/Version 25/05/2013 Executive Summary (Rep.). Luxembourg: ESPON.

[45] European Anti Poverty Network (2007). Services of General Interest: Glossary and terms explained. Brussels: European Anti Poverty Network.

[46] European Commission (2011). Communication from the commission to the European parliament, the council, the European economic and social committee and the Committee of the regions: A Quality Framework for Services of General Interest in Europe. Brussel: European Commission.

[47] European parliament (2006). Directive 2006/123/EC of the European Parliament and of the Council of 12 December 2006 on services in the internal market. EUR - Lex, L 376/36.

[48] European Union (2012). Charter of Fundamental Rights of the European Union, 26 October 2012, 2012/C 326/02.

[49] Fama (2018). Fama Vipava - Veriga marketov ter oskrba gostinstva]. Available at: https:// www.fama.si/o-podjetju-fama [Accessed 9. 1 2019].

[50] Jankovič, M. (2017). Gospodarska rast v 2016 v obalno-kraški regiji 6,0-odstotna, v osrednjeslovenski in gorenjski 4,5-odstotna. Available at: http://www.stat.si/ StatWeb/News/Index/7131 [Accessed 25. 9. 2018].

[51] Kolarič, Š., Marot, N., Černič Mali, B. \& Kostanjšek, B. (2017). Report on comparison analysis [Deliverable 1.2.3]. Ljubljana: University of Ljubljana. 
[52] Ministers for Urban Development and Territorial Cohesion (2007). Territorial Agenda of the European Union: Towards a More Competitive and Sustainable Europe of Diverse Regions. Berlin: Bundesministerium für Umwelt, Naturschutz, Bau und Reaktorsicherheit.

[53] Nared, J., Smrekar, A., Bole, D., Kozina, J., Fridl, J., Polajnar Horvat, K., Gabrovec, M. \& Repolusk, P. (2011). Inovativna strategija trajnostnega razvoja Občine Idrija. Ljubljana: Anton Melik Geographical Center, Scientific Research Center of the Slovenian Academy of Sciences and Arts.

[54] Odlok o občinskem prostorskem načrtu občine Cerkno]. (2013). Uradni list RS, 38,13, 34203500.

[55] Odlok o občinskem prostorskem načrtu občine Idrija]. (2011). Uradni list RS, 38,11, 51295158.

[56] Rural Development Programme 2014-2020 (2020). [online] Program-podezelja.si. Available at: <https://www.program-podezelja.si/en/rural-development-programme-2014-2020> [Accessed 20 November 2020].

[57] Spatial Foresight, BMI (Federal Ministry of the Interior, Building and Community) and BBSR (Federal Institute for Building, Urban Affairs and Spatial Development) (2020). Draft Territorial Agenda 2030 [online]. Available at: https://www.territorialagenda.eu/files/agenda_theme/agenda_data/Revisions\%20\%20Draft\%20documents/Draft-TerritorialAgenda2030_July2020.pdf [Accessed 20. 11. 2020.]

[58] Statistical Office of the Republic of Slovenia (2018). Demography and social statistics, Population by selected age groups and sex, municipalities, Slovenia, semi-annual [online]. Available at:

https://pxweb.stat.si/pxweb/Dialog/varval.asp?ma=05C4008S\&ti=\&path=../Database/Dem soc/05_population / 10_stevilo_preb / 20_05C40_publication_obcine / \& lang = 2 [Accessed 12. 10. 2018].

[59] Swiss Working Group for Mountain Areas - SAB (2007). Provision of public services in alpine areas: State of the art - recommendations - good practice. Final report of the Interreg III $B$ project PUSEMOR. Bern: SAB. Available at: http://www.alpine-space.org/20002006/uploads/media/PUSEMOR_final_report.pdf [Accessed 20. 9. 2018].

[60] Telekom Slovenije (2019). Accessibility of the optical network [Dostopnost optičnega omrežja]. [online]. Available at: https://www.telekom.si/pomoc-in-podpora/temepomoci/pokritost-in-dostopnost/dostopnost-opticnega-omrezja [Accessed 4. 2. 2019].

[61] UNESCO (2019). Vocabularies UNESCO. Thesaurus: Basic needs. [online]. Available at: http://vocabularies.unesco.org/browser/thesaurus/en/page/?uri=http://vocabularies.unesco. org/thesaurus/concept3614 [Accessed 14. 1. 2019].

[62] Zeleni zabojček (2018). Zeleni zabojček - Local eco-food. [Lokalna ekohrana]. [online]. Available at: http://zelenizabojcek.si/za/ [Accessed 29. 12. 2018]. 